\title{
The Dis-membered Body: Bodily Fragmentation as a Metaphor for Political Renewal
}

RAINER GULDIN ${ }^{l}$

\section{ABSTRACT}

In recent years, the theme of bodily fragmentation has received much attention in academic studies in Europe. The body and its parts have come to be viewed as text, trope, or metaphor, allowing one to think of the social systems. Based on contemporary reflections dealing with the body as text or discourse, including Mikhail Bakhtin, Stefanie Wenner, and Jacques Lacan, the current article revisits Empedocles and Plutarch to discuss particularly the anthropological and philosophical aspects of the concepts that have been constructed concerning the body.

Keywords: Body; discourse, Stefanie Wenner. 
In the last few years the theme of bodily fragmentation has received extensive scholarly attention throughout Europe. The issue has been dealt with from a wide range of theoretical points of view: anthropological, aesthetical ${ }^{1}$, ethnographic, historical, literary and sociologic, to mention only a few. I am going to review briefly some of the more prominent and interesting examples I have come across trying to define through this my own theoretical framework and therewith leading the reader up to the main subject of this essay: the fundamental interconnectedness and reversibility of body-unity and body-fragmentation as it can be encountered in narratives about the birth and renewal of social units, a theme that has received little attention so far.

The sociologically oriented journal Body and Society published in the United Kingdom has dedicated a special issue to the subject of 'Commodifying bodies'. In her foreword, Bodies for Sale - Whole or in Parts, one of the editors, Nancy Scheper-Hughes, points out wryly that

"while in the academy (as in this journal) 'the body' is generally treated as a text or a trope or as a metaphor that is 'good to think' with, in the larger society and in the global economy the 'body' is generally viewed and treated as an object, albeit a highly fetishized one, and as a 'commodity' that can be bartered, sold or stolen in divisible and alienable parts. (...) contributing to new forms of late modern cannibalism" (Scheper-Hughes, 2001, p. 1).

The individual bodies of the lower classes of third-world countries are turned into ready-made organ-repositories to be plundered at will by the international business of organ-trafficking. An example quoted by ScheperHughes in her foreword should suffice to illustrate the darker side of the issue of body fragmentation: a Madras slum-dweller, living on the brink of starvation because of crippl ing debts due in part to the incapacity of her husband to earn a living, decides to sell one of her kidneys. In this way by sacrificing a 'disposable' part of her body she will be able to come to the rescue of her family, literally to feed it through a gesture of self-cannibalism.

A less apocalyptical vision more in tone with the conception of the body as text and the text as body that I want to pursue in my article can be found in a fascinatingly heterogeneous series of essays going back to an international conference held in May 2000 at the Haus der Kulturen der Welt in Berlin in collaboration with the Freie Universität Berlin. The collection published under the title Körperteile. Eine kulturelle Anatomie - Body-parts. A Cultural Anatomy - explores various aspects of the phenomenon (Benthien and Wulf, 2001). 
Moving from 'top to toe', the single contributions, loosely arranged in four main sections - head, trunk, sexual organs and body extremities -, deal with single body parts from a wide choice of theoretical and thematic standpoints. The general structuring principle itself is dictated by the main subject of the book, the reciprocal relationship of fragmentation and reconstitution. Each part of the body is thus called upon to tell its own story about lost and regained unity and the self-defeating attempt at reconstituting the overall puzzle of the disconnected parts. Content and method comment upon each other. The idea of the fragment and the fragmentary goes thus hand in hand with a theoretical stance that presupposes the impossibility of a unifying discourse, that is, of a teleological and globalizing narrative about the history of the human body. The body of research is only to be had in separate pieces whose relationships to each other and the whole vary continuously as one moves from one point of view to the other. The idea of reassembling the different parts of a body of discourse is here also used to stress the constructivist side of every kind of theory-building activity. This aspect is of particular importance in the case of the human body long considered to be the sole object of the natural sciences and only recently turned into a subject of the humanities.

The tension between wholeness and fragmentation with respect to the (im)possibilities of a history of the human body is captured in the title of one of the early attempts to reunite the scattered pieces of the shattered picture, the three volume edition of Fragments for a History of the Human Body. In the introduction Michel Feher writes programmatically " $(\ldots)$ the history of the human body is not so much the history of its representations as of its modes of construction. For the history of its representations always refers to a real body considered to be 'without history' - whether this be the organism observed by the natural sciences, the body proper as perceived by phenomenology, or the instinctual, repressed body on which psychoanalysis is based - whereas the history of its modes of construction can, since it avoids the overly massive oppositions of science and ideology or of authenticity and alienation, turn the body into a thoroughly historicized and completely problematic issue" (Feher, Naddaff and Tazi, 1989, p. 11). This point of view holds particularly true with regard to the ideological use of body-imagery in political discourse. But I will come to this shortly.

The volume The Body in Parts, dedicated to early modern Europe ${ }^{2}$, chooses a slightly different approach. Although the title seems to suggest Lacan's corps morcelé or Foucault's conception of the rupture of symbolic 
Rainer Guldin

and social fields, it is less about a body in 'pieces' than a body in 'parts', that is, a body constituted by a multiplicity of individuated organs. Fragmentation, therefore, does not lead to the lamentable loss of organic unity but to the accentuation of the individual character and importance of each organ. The single parts are not discarded pieces of a shattered whole, but individual units of the body in which specific aspects of culture are imagined to reside ${ }^{3}$.

This particular view recalls Mikhail Bakhtin's conception of the 'grotesque body' which articulates a carnivalesque vision of the world negating the hierarchic conception of late-medieval society embodied in the organic vision of the 'body politic' (Bakhtin, 1965). The single organs, especially the belly ${ }^{4}$, but also the nose, the female breasts and the sexual organs claim their independence trying to break away from the unity of the body. In this world turned upside-down (Babcock, 1978) the lower half of the body comes into its own right again symbolizing through this a rejection of the political and ideological hegemony of the ruling classes. Radical social change is expressed in the imagery of broken corporeal unity as in the example we will deal with at the end of this essay.

Two specific variants of this political discourse can be found in the metaphor for bodily amputation and the social upheaval ensuing after "the death of the king". In the first case sick or rotten parts have to be cut off for the sake of the rest of the social body, a metaphor very popular in times of sedition or open rebellion ${ }^{5}$. The second case regards phases of political change occurring when the king dies, leaving the seat of power temporarily vacant, a dangerous transition period generally known as interregnum. As the body falls into pieces in the process of decomposition social ties and laws no longer apply. Stability and structure will finally prevail again when a new king or leader is enthroned. In this particular instance the health of the body of the ruler corresponds to the well-being of the state as a whole ${ }^{6}$.

In an essay exploring some of the historical origins of the paradigm of body partitioning, Stefanie Wenner tries to show how the image of fragmentation always corresponds to and presupposes its opposite: the image of wholeness (Wenner, 2001, p. 339-380). In fact, without any previous idea of a unity that can be lost through dismemberment the concepts of fragment and fragmentation would be meaningless. The dis-membered body is the body whose original members making up its unity have been torn asunder. Let me briefly outline some of her conclusions.

Lacan's classical analysis of the mirror-stage of psychological evolution 
draws upon the idea that the child manages to overcome a fundamental experience of bodily fragmentation only when meeting with the image of his intact self in the mirror. The idea of fragmentation presupposes here that unity is something that needs to be constructed. But the question is: Why should the child's primary bodily experience be one of fragmentation? And why does Lacan prefer dismemberment rather than unity as the starting point for his analysis?

Lacan does make the phantasmatic nature of the image of the whole body apparent but by placing the stage of fragmentation before the achievement of unity his argumentation acquires a teleological drift. At the same time he fails to understand properly the culturally productive aspects of bodily partitioning. Add to this the fact that the fragmented body itself always appears within a specific representational framing. What looks to be a fundamental stage of any human development, the birth of unity out of a chaotic jumble of pieces, is in fact already a historically and culturally coded experience. Dismemberment is the fundamental paradigm of modernity ${ }^{7}$ and as such secretly structures Lacan's own discourse. In the course of the $16^{\text {th }}$ and $17^{\text {th }}$ century the medical discourse formed itself in connection with the dissecting of corpses fighting against the tenacious taboo of violating the corporeal integrity of the dead. The anatomy of the human body became a fundamental metaphor for modern scientific investigation ${ }^{8}$.

The predominant post-modern body conception owes much more to the pleasure of dissecting than to the search for unity and completeness. Furthermore, the development of bodily prostheses was possible only on the basis of the previous historical experience of anatomical dismemberment initially celebrated in the baroque spectacle of the theatrum anatomicum (Böhme, 1991, p. 180-198). More than substitutes for lost or injured limbs, prostheses have turned out to be revolutionary means of expanding and increasing the range of body-activity. The cyborg, integrating organic and prosthetic components, is the last stage so far in a long evolution that was only possible because of the all pervading paradigm of fragmentation. Instead of the one sided prevalence of unity over fragmentation or vice versa, Wenner suggests therefore a theoretical vision that relies on the basic reversibility of body-imagery, pointing out that each image will have to be analyzed according to its particular historical context. Both images, that of unity and that of fragmentation, are basically inadequate leaving the emplacement of the body unoccupied. The fundamental reversibility of bodyimagery, on the other hand, "shows that bodies remain clearly visible or stay 
Rainer Guldin

hidden in the space opened up by the oscillation of body-imagery" (Wenner, 2001, p. 379).

I would like to take Wenner's theoretical perspective as a starting point for my own reflection about the reversibility of body unity and body fragmentation, expanding the discourse into the historical and political domain to show how the imagery of bodily unity and fragmentation has also been widely and systematically used over the centuries to illustrate and justify both social continuity and revolutionary change. In the first case it is the allotment of individual organs to specific social groupings through sacrificial partition of a body symbolizing society as a whole. In the second case the imagery of dismemberment has been used to justify a radical breaking away from the traditional social setting. In the specific example I have chosen its use implies at the same time a rupture with the paradigm as it had been employed up to that point. Before getting there, however, I would like to discuss some of the purposes the paradigm has been put to use within the framework of Indo-European culture ${ }^{9}$.

Empedocles' cosmic vision postulates the eternal struggle of two opposed forces: Love and Strife, one of them acting to (re)unite things, the other bound on destruction, severing ties and cutting things apart. When love prevails the elements of the universe assume temporarily the form of a perfect undifferentiated sphere. In the other situation they get torn apart and whirl around at great speed in constant fight with each other. Undifferentiated unity alternates cyclically with fragmented multiplicity in reciprocal alternation, each stage giving rise to the next one in turn. In one particular fragment Empedocles' calls the single elements limbs implying by this the notion that the unified whole can also be considered a (human) body. The transition from unity to fragmentation thus takes place through dismemberment whereas the opposite passage can be seen as the result of the reassembling of scattered limbs.

Empedocles' vision articulates one of the fundamental patterns of IndoEuropean cosmogony that uses the human body as a metaphor for the world establishing a subtle system of correspondences between the four elements, the plants, the animals and the parts of the body. The same structure acknowledging creation through dismemberment can be found in a series of mythological and political narratives explaining the coming into being and the periodical renewal of social configurations. In all of these stories the sacrificed person in question, mostly the king, stands for the society he rules, in fact he incorporates it in its totality ${ }^{10}$. 
Several cosmological myths of origin within the Indo-European tradition can also be interpreted as 'sociogonies', that is, narratives about the birth of society as a differentiated system of classes. The Rig Veda, written in the ninth century B.C., tells the story of the dismemberment of the primordial giant Purusa giving rise through this to the cosmos and the Indian castesystem: from his brain came the moon, from his eyes the sun, from his mouth came fire, from his breath the wind and from his feet the earth. At the same time the Brahmans were born from his mouth, the warriors from his arms, the people from his thighs and the servants from his feet.

In the $27^{\text {th }}$ chapter of his Life of Romulus, the early mythical Roman king, Plutarch tells how the senators rebelled and killed their ruler dismembering his body in the temple of Hephaistos and distributing the pieces among themselves, each of them hiding a part in the folds of their robes with the intention of carrying them away with them. Each of the senators represents one of the Roman families, the gentes, which were bound together by a system of mutual support and interdependence. "The distribution of Romulus's bodily parts is thus a mythic sociogony, describing the creation of a differentiated social order in which no gens could claim totality or absolute supremacy, but in which each had a role to play in the functioning of the city. (...) A convocation of all Roman gentes reunified the pieces of Romulus's dismembered body (...) and each adjournment of the senate repeated the dispersion of his bodily parts" (Lincoln, 1986, p. 43). In this particular case the nature of the bodily part assigned to each senator is not specified as these are politically speaking all equals. The dismembered body of the king guarantees the coexistence of a select group of rulers and at the same time the absence of a primus inter pares that could easily become the new king. The power is in the hands of all senators and only at the moment they come together to deliberate.

The culminating act of the Feriae Latinae, a celebration where delegates from all 47 Latin cities under Roman rule assembled, consisted in the sacrifice of a bull. The bigger and more prestigious a city the larger and more important the portion it was allotted. The other lesser members of the federation received cuts of meat adequate to their specific rank and power. The ceremony took place under the control of the Romans, who had conquered the area in the seventh century B.C. Social solidarity is expressed in terms of the intact body of a bull and social difference and separation is articulated in the distribution of the unequal pieces of the dismembered corpse. With regard to the first example, however, there is an important difference to be pointed 
out. The diverse members of the political alliance are under the dominion of a central power which cultivates the inequality of its affiliates in order to consolidate its own hegemonic position.

The conception of the human body as a whole of integrated parts different from each other and therefore possessing a specific function of their own - often associated with a hierarchical position on a vertical axis - has been used to argue in favour of a strict class-society. The ideological force of the argument arises from the supposed naturalness of such a vision of the human body. In the same way as the human body is made up of a certain number of organs with different functions each in its own way important to a proper functioning of the whole a well-organized social system needs different social-classes. But as Wenner rightly points out in her essay (Wenner, 2001, p. 378) it is this very alleged naturalness of the (human) body as an integrated whole that needs to be questioned. From a historical point of view in fact the human body has never been such a unified entity, but always a fragile picture resulting from the piecing together of dissimilar parts.

The organic vision of the city as a body and the body as a city is another widespread socio-political model of interpretation. In Greek antiquity the knife of the sacrificial priest was considered an instrument of power cutting out every time anew the ritually determined part for each social segment. The pieces of the sacrificial animal bear witness to the civil inequality of the inhabitants. The guild of the blacksmiths, for instance, is attributed the brain because of its symbolical connection to their patron-goddess Athena, born from the head of Zeus ${ }^{11}$.

But it is the political discourse of the death and dismemberment of the body of the king followed by its reconstitution and resurrection that most aptly illustrates the idea of structural reversibility I am interested in here. The body of the king stands for society as a whole and contains therefore its basic components in form of the essential characteristics associated with each class. In the same way, as the single classes have been used to make up the body of the king, the constituent classes of society were created from the dismembered body of the first mythical man who, as we have seen in the example described by Plutarch, happens in some cases to be the first mythical king himself.

Bruce Lincoln describes an Irish legend, the story of Lugaid Red Stripes, which perfectly illustrates the alternation between partitioning and reassembling I have been dealing with so far. The stage of dismemberment corresponds to a sociogony, whereas the stage of reconstitution amounts to what Lincoln 
calls a 'regiogony', the coming into being of a new king.

Before Lugaid was born the three sons of the king of Tara, Bres, Nár and Lóthar decided to rebel against their father. But they were defeated and killed in the battle of Druim Criaich and their heads cut off and brought to the victorious king. But the night before the decisive confrontation their sister Clothru came to visit them at the encampment begging them to have pity upon her childless state and persuading the three to have sexual intercourse with her in order for a son to be born. The three sons represent three distinct traits of character and the child born from this incestuous union will reunite all of them in one person. Bres means to fight, to battle, it stands for military courage, nár on the other hand stands for nobleness of the soul, for wisdom and generosity and finally lóthar means channel, trough or washbasin, denoting some lowly activity. When Lugaid was born his body was divided into three distinct parts by two red stripes running around his neck and waist. His head looked like that of the wise and noble Nár, his breast like that of the courageous and fiery Bres and from the waist downward he looked like Lóthar. After many a battle Lugaid managed to become king of Tara but after twenty-six years of judicious government he was killed by three men who had already made themselves a name as slaughterers of kings. And therewith a new cycle sets in.

A similar tripartite division, without any organic analogy however, can be found in a passage form the forth book of Herodotus' Histories. As in the Irish legend of Lugaid the three distinct parts of society are incorporated into the person of the ruler. Herodotus describes a primordial myth of the Scythians. The first man to live in that part of the world when it was still empty and inhospitable was Targitaos. He conceived three sons Lipoxais, Arpoxais und Kolaxais. When he had to decide who of the three was going to be king three golden objects fell from the sky: a plough, a fighting axe and a cup. These three objects symbolize the three main classes of Scythian society: the peasants, the warriors and the priests. Only the youngest of the three, Kolaxais, managed to get hold of all three objects convincing his brothers that he was to be the successor of their father.

I would like to conclude my short excursion with the reading of a particularly interesting text that signals a turning-point in the tradition sketched so far. The text in question, an anonymous pamphlet, a sort of political fairy tale written on the $23^{\text {rd }}$ April 1789, that is, on the eve of the French revolution, narrates the story of a gentle but slow-witted giant known under the name of 'Fort-par-les-bras' and his two despicable brothers, the knightly 'Paladin' 
Rainer Guldin

and the charming Proteus like 'Enchanteur', all three of unknown father, yet born from the fertile womb of France. The three main political forces of the Ancien Régime - the third estate, the aristocracy and the clergy - as well as the ideological tendency of the story are clearly recognizable. Once more we come across the idea of social division personified in three separate bodies and, although the solution to be looked for will again be that of a reunification of the different parts in one single organism, this time we can observe an ever so slight but essential shift of accent.

Although the giant is a healthy stripling, his head is exceedingly small, giving him an altogether monstrous appearance. Not before long a merciless fight between him and his two bastardly brothers - "misérables avortons, fils des ténèbres qui avait violé la mère" - begins. In its course the heads of 'Paladin' and 'Enchanteur' swiftly merge into each other. Without any hesitation 'Fort-par-les-bras' cuts the Siamese twins in half at the waist, chopping off their entwined upper body-regions which lightly float away like two hot-air balloons. Their lower parts though

"qu'ils nommaient dédaigneusement aux siècle de la tyrannie, leur parties basses, et que nous autres, historiens anatomistes, nous appelons leur parties nobles, restèrent debout, sur la terre, et elles offrirent au regard de Fort-parles-bras un nouveau spectacle qui le fit pleurer de tendresse. Ces deux parties étaient composées d'un faisceau de petits géants, mâles et femelles, tous nus, tous maigres, tous bambins, presque sans force et sans mouvement. Et peu à peu il vit leurs paupières s'entrouvrir, leu cœur palpiter, leurs petits pieds affermir; et ils étendaient leurs petits bras vers lui, comme pour l'embrasser et ne plus former avec lui qu'une seule et unique réunion" (De Baecque, 1993, p. 132-4).

Delivered from the domination of the upper-part of the body tragicomically fizzling away like hot air once they have been truncated from their anchorage, the lower body-domain is born to new life again. The single parts, however, are no longer the lesser organs of a hierarchically organised whole. They are now the dismembered parts of a democratic society of little giants all equal to each other striving to become one with their bigger counterpart and liberator. The author uses a series of symbolical inversions to drive his meaning home. The death of clergy and aristocracy, being the parasitical upper-part of the 'body politic', is the beginning of a new life for the whole of society. The two bodies are cut in half falling into pieces equal to each other and held together by a newly discovered common feeling of democratic 
solidarity negating the feudal conception of organic interdependency based on the inequality of the single parts - that is: the head and the heart controlling the stomach and the bowels. And finally: the lower body-regions are reevaluated and thus redeemed from the inferior role they had been playing within the discursive context of the metaphor for the 'body politic' going back as far as Platon's Republic ${ }^{12}$. By cutting off their upper-part the lower body-regions come to a new life again. The nakedness of the little giants is a symbol of complete political rebirth.

The last section of the story is a fitting illustration of the principle of representative parliamentary democracy. 'Fort-par-les-bras', still stunned by the success of his military prowess, is promptly and miraculously invaded by a new intellectual vision growing spontaneously within his brain and leading him to listen with friendly feelings to the many little voices clamouring to be heard. It is through his mouth that they are all going to speak. The giant takes them into his arms and hugs them close to his heart. The social division represented by the three unequal brothers ${ }^{13}$ is thus finally overcome by the unifying vision of the many little giants, all and singularly speaking through their one overall representative.

Political and social renewal is arrived at by a movement of fragmentation followed by a subsequent re-composition of the single parts arranged in a new pattern. Although the two moments are inseparable from each other the movement involved here is not circular: it does not lead back to the beginning starting another loop but jumps unto a completely new level of organization. The tradition reconstructed so far was using the cyclical alternation of unity and fragmentation to ensure the continuity of a political setting rooted in inequality. The ruler incorporated in his symbolical body the three - sometimes four - different classes, each corresponding to one particular part of a vertically organized whole. Here the narrative deliberately abandons the closely-knit biological analogy of the 'body politic' based on a hierarchical system of correspondences between organs, body parts and social groups. It conceives unity as an ideal coming together of equal members reunited by a common dream.

The tradition I have briefly tried to sketch here confirms Wenner's hypothesis of the symbolical reversibility of unity and fragmentation. It supplements it with material taken from a completely different domain, that of the organic metaphors for the body-politic. It is in this discursive arena that 'natural' conceptions of the body clearly show their hidden ideological side. Natural metaphors in political discourse can very often be traced back 
Rainer Guldin

to an already politically interpreted natural condition - as for instance in the case of Aristotle's view of the state - revealing the circular character of such definitions. The examples discussed above show the questionability of concepts of bodily coherence, revealing their highly ideological character. These assumptions are not given but always need to be renegotiated anew.

\section{References}

BABCOCK, B. Reversible world: symbolic inversion in art and society. London, 1978.

BAKHTIN, M. Rabelais and his world. Cambridge, 1965.

BENTHIEN, C.; WULF, Ch. (Ed.). Körperteile. Eine Kulturelle Anatomie. Reinbek bei Hamburg, 2001.

BÖHME, H. Erotische Anatomie. Körperfragmentierung als ästhetisches Verfahren. In: BENTHIEN, C.; WULF, Ch. (Ed.). Körperteile. Eine Kulturelle Anatomie. Reinbek bei Hamburg, 2001, p.228-253.

. Eine Schematisierung von Zerstückelungsphantasien. Über einen

Urprung der Fichte'schen Literatur. In: Leben, um eine Form der Darstellung zu errei-chen. Studien zum Werk Hubert Fichtes, Frankfurt am Main 1991, p.180-198.

BRESC-BAUTIER, G. 'Exvoto'. Das Fragment. Der Körper in Stücken. Ed. by Schirn Kunsthalle Frankfurt. Frankfurt am Main, 1990, p. 38-42.

DUPONT, F. The Emperor-God's Other Body. In: FEHER, M.; NADDAFF, R.; TAZI, N. (Eds.). Fragments for a history of the human body. Part Three. New York, 1990, p. 396-419.

DE BAECQUE, A. Le corps de l'histoire. Métaphores et Politique (17701800). Paris, 1993.

DE HEUSCH, L. The Sacrificial Body of the King. In: FEHER, M.; NADDAFF, R.; TAZI, N. (Eds.). Fragments for a history of the human body. Part Three. New York, 1990, p. 387-394.

FEHER, M.; NADDAFF, R.; TAZI, N. (Eds.), Fragments for a history of the human body. New York, 1989-1990.

GULDIN, R. Körpermetaphern. Zum Verhältnis von Politik und Medizin. Würzburg, 2000.

HALE, D. G. Intestine sedition: the fable of the belly. In: Comparative Literary Studies 5 (1968), p. 377-388. 
. The body politic. A political metaphor in Renaissance English Literature. The Hague and Paris, 1971.

HILLMAN, D.; MAZZIO, C. (Eds.). The body in parts: fantasies of corporeality in early modern Europe. London, 1997.

LINCOLN, B. Myth, cosmos and society. Indo-European themes of creation and destruction. London, 1986.

KAMPER, D. Das Phantasma vom Ganzen und vom Zerstückelten Körper. In: KAMPER, D.; WULF, Ch. (Eds.). Die Wiederkehr des Körpers. Frankfurt am Main, 1984, p. 125-134.

NOCHLIN, L. The body in pieces. The fragment as a metaphor for Modernity. London, 1994.

PEIL, D. Untersuchungen zur Staats und Herrschaftsmetaphorik in literarischen Zeugnissen von der Antike bis zur Gegenwart. München, 1983.

SAWDAY, J. The body emblazoned. Dissection and the human body in Renaissance Culture. New York, 1995.

SCHEPER-HUGHES, N. Bodies for sale - whole or in parts. Body and Society, v. 7, n. 2-3, Sept., 2001, p. 1-8.

SVENBRO, J. La découpe du poème. Notes sur les origines sacrficielles de la poétique grecque. Poétiqu,e n. 58, Apr., 1984.

. A Mégara Hyblaea: le corps géomètre. Annales, n. 56, 1982.

VEGETTI, M. Il coltello e lo stilo. Le origini della scienza occidentale. Milano, 1996.

WENNER, S. Ganzer oder zerstückelter Körper. Über die Reversibilität von Körper-bildern. In: BENTHIEN, C.; WULF, Ch.(Eds.). Körperteile. Eine Kulturelle Anatomie. Reinbek bei Hamburg, 2001, p. 339-380.

\section{NOTES}

1 Compare Bresc-Bautier (1990, p. 38-42).

2 Compare Sawday (1995).

3 See Hillman and Mazzio (1997, p. xi).

4 The fable of the rebellious belly refusing to do his work and dying with the rest of the exhausted body, told by the Roman historian Titus Livius, has a long tradition within political discourse. See HALE (1968, p. 377-388) and HALE (1971).

5 Compare Peil (1983). 
Rainer Guldin

6 See Guldin (2000, p. 103-123).

7 See also Kamper (1984, p. 125-134).

8 See also Vegetti (1996). His reconstruction of the historical origins of western scientific thought sets in at an even earlier moment. He sees a connection at work between sacrificial rituals and analytical methods of investigation in ancient Greece.

9 For the following compare Lincoln (1986).

10 Compare De Heusch (1990, p. 387-394 and 396-419).

11 See Svenbro (1982).

12 Compare Guldin (2000, p. 27-98).

13 As in the previous examples three in one, but this time with the difference that from two of them only the 'better', that is the lower part, has been taken up into the new unity.

\section{RESUMO}

O Corpo Dis-membrado: Fragmentação Corporal como Metáfora para Renovação Política

Nos últimos anos o tema da fragmentação do corpo tem recebido muita atenção dos estudos acadêmicos na Europa. Passa-se a ver o corpo e suas partes como texto, tropo ou metáfora que permitem pensar os sistemas sociais. A partir das reflexões contemporâneas que tratam o corpo como um texto ou um discurso, passando por Mikhail Bakhtin, Stefanie Wenner e Jacques Lacan, o presente artigo retorna a Empedocles e Plutarco para discutir os aspectos antropológicos e filosóficos, principalmente, das concepções que se vêm construindo sobre o corpo.

Palavras-chave: Corpo; discurso; Stefanie Wenner.

Recebido em: 24/09/2002.

Aprovado em: 12/11/2002. 


\title{
Margem de Papel ou Corpo Despedaçado do Texto ${ }^{1}$
}

\author{
PAULO SÉRGIO NOLASCO DOS SANTOS ${ }^{2}$
}

$\mathrm{O}$ artigo propõe-se a refletir a travessia dos signos do universo socioeconômico do Estado do Mato Grosso do Sul e a constituição da identidade e representação em textos diversos da literatura e da crítica cultural que tematizam a questão. Adotando uma perspectiva baseada na crítica cultural e/ou nos estudos culturais, o artigo analisa a complexidade da relação entre narração e representação, elaborando uma síntese da noção de região num espaço que compreende o entorno do pantanal sul-mato-grossense. As conclusões do trabalho indicam que a travessia e circulação dos signos culturais se dão enquanto agenciamento discursivo, que ora reflete o objeto da representação, ora o mascara, pois a natureza desse objeto se demonstra enquanto tecido emblemático de um corpo despedaçado.

Palavras-chave: Identidade e representação; estudos culturais; crítica. 